\title{
Evaluation of Design and Operational Parameters of Pilot Single Stage Stabilization Pond for Treatment of Brewery Waste Water Effluent
}

\section{Okonkwo $\mathrm{PC}^{1^{*}}$ and Umar Musa ${ }^{2}$}

${ }^{1}$ Department of Chemical Engineering, ABU Zaria University, Kaduna, Nigeria

${ }^{2}$ Department of Chemical Engineering, Kaduna Polytechnic, Kaduna, Nigeria

\begin{abstract}
The suitability of waste stabilization pond (WSP) as a cheaper alternative in the treatment of brewery wastewater effluent was investigated. A pilot WSP was designed and constructed and test run for the treatment brewery wastewater effluent. Wastewater effluents were collected from an operating brewing industry in Kudenda light industrial layout, Kaduna. The influent pond flow rate of $0.2 \mathrm{~m}^{3} /$ day was chosen for the design of the pilot pond. Kinetic model design procedure of a facultative pond was used to design a rectangular shaped pond to reduce the BOD loading by $90 \%$. The pond capacity was $4.7 \mathrm{~m}^{3}$ (4700 litres) with a retention time of 25 days. The parameters that were analyzed for the raw and treated wastewater include: Biological Oxygen Demand $\left(\mathrm{BOD}_{5}\right)$, Chemical Oxygen Demand (COD), Total suspended solids (TSS), Turbidity and Electrical conductivity (EC). It was observed that aerobic degradation occurred at the upper layer of the pond favoring the activities of aerobic bacteria At the middle layer however favored the activities of the facultative bacteria, while at the lower level where there is virtually little or no presence of dissolved oxygen, anaerobic decomposition of the wastewater predominate. These combined mechanisms yielded the total the total decomposition of the wastewater by the pond. The BOD removal rate constant was 0.088 per day and the $B O D-C O D$ correlation was $B O D=0.531 C O D-1.960$. The $B O D$ removal regression model was: $B O D=0.0001 t^{5}-0.0034 t^{4}-0.1419 t^{3}+6.6096 t^{2}-102.09 t+1114.5$ and the pond performance efficiencies for the reduction/removal of the tested parameters $69 \% 68.9 \%, 81 \%, 67.2 \%$ and $71.6 \%$ respectively. The pond performance was found to be satisfactory and the kinetic parameter obtained can be utilized in the scale up design for industrial scale WSP.
\end{abstract}

Keywords: Stabilization pond; Brewery waste water; BOD; COD

\section{Introduction}

The world's population explosion has resulted into increase in domestic, agricultural and industrial activities to cater for human needs for survival. This has also led to the increase in generation of wastewater. Although we recognize the fact that water is undoubtedly the most precious natural resource that exists on our planet, we disregarded it by polluting our rivers, lakes and oceans with generated wastewaters. It is therefore the basic duty of every individual to conserve water resources [1]. The construction of cost effective standard wastewater treatment plant coupled with requirement of technical expertise has been a major barrier for the implementation of modern technologies by local authorities in many developing nations $[2,3]$. Consequently, developing nations are unable to incorporate these technologies as part of a wastewater treatment master plan [4]. It is therefore imperative to develop treatment systems that are economical and sustainable [1]. Waste Stabilization Ponds (WSPs) have been found to be a suitable alternative for wastewater treatment for tropical and subtropical countries since the sunlight irradiance and ambient temperature are key factors for the WSP process efficiency [5,6]. Treatment occurs through natural, physical, chemical and biological processes and no energy or machinery is required except sun light energy. According to [4], stabilization ponds are the preferred wastewater treatment process in developing countries such as Nigeria where land is often available at reasonable cost and skilled labor is in short supply. The most appropriate wastewater treatment is that which will produce an effluent meeting the recommended microbiological and chemical quality guidelines both at low cost and with minimum operational and maintenance requirements [7]. The main focus of this study was to investigate with pilot-scale experiment, the suitability of WSP in the treatment of brewery wastewater effluents and the treatment performance of a pilotscale WSP

\section{Pond design}

Specifications: Design a pilot waste stabilization pond to treat 0.2 $\mathrm{m}^{3}$ brewery wastewater per day.

- From the analysis of the brewery waste water carried out, the average $\mathrm{BOD}_{5}$ of the brewery Wastewater is $1135.5 \mathrm{mg} / \mathrm{L}$

- Mean ambient temperature in the coldest season in Kaduna metropolis where the pond is sited is $28^{\circ} \mathrm{C}$

- Pond depth=1.2 m (adequate for aerobic and facultative ponds; Tchobanoglous, 2000)

- BOD removal target is $90 \%$

- For $90 \%$ BOD removal the BOD removal is $0.90 \times$ $1135.5=1021.95 \mathrm{mg} / \mathrm{L}$

Therefore:

Effluent BOD=1135.5-1021.95=113.55 mg/L

Kinetic model approach for facultative pond is employed in this design. The values of the design parameters used in the design calculations and the pond configurations obtained are presented in Tables 1 and 2 .

*Corresponding authors: Okonkwo PC, Department of Chemical Engineering ABU Zaria University, Kaduna, Nigeria, Tel: +2347067430505; E-mail: chemstprom@yahoo.com

Received August 03, 2017; Accepted August 21, 2017; Published August 23 2017

Citation: Okonkwo PC, Musa U (2017) Evaluation of Design and Operational Parameters of Pilot Single Stage Stabilization Pond for Treatment of Brewery Waste Water Effluent. J Adv Chem Eng 7: 178. doi: 10.4172/2090-4568.1000178

Copyright: ( 2017 Okonkwo PC, et al. This is an open-access article distributed under the terms of the Creative Commons Attribution License, which permits unrestricted use, distribution, and reproduction in any medium, provided the original author and source are credited. 


\begin{tabular}{|c|c|c|}
\hline Parameter & Unit & Mean Value \\
\hline $\mathrm{pH}$ & - & 3.56 \\
\hline Temperature & ${ }^{\circ} \mathrm{C}$ & 29.34 \\
\hline Suspended solids & $\mathrm{mg} / \mathrm{L}$ & 1040 \\
\hline Turbidity & $\mathrm{NTU}$ & 5.96 \\
\hline Chloride & $\mathrm{mg} / \mathrm{L}$ & 618.2 \\
\hline $\mathrm{BOD}_{5}$ & $\mathrm{mg} / \mathrm{L}$ & 1135.5 \\
\hline $\mathrm{COD}$ & $\mathrm{mg} / \mathrm{L}$ & 2134.74 \\
\hline Conductivity & $\mu \mathrm{ss} / \mathrm{cm}$ & 1130 \\
\hline Total Dissolved Solids & $\mathrm{mg} / \mathrm{L}$ & 862 \\
\hline Total Coliform & E. coli/100 $\mathrm{ml}$ & 0.7 \\
\hline
\end{tabular}

BOD: Biochemical oxygen demand; COD: Chemical oxygen demand

Table 1: Analysis of Brewery Wastewater effluent in Kudenda, Kaduna, Nigeria.

\begin{tabular}{|c|c|}
\hline Design Parameters & Pond Dimensions \\
\hline Temperature $\left(28^{\circ} \mathrm{C}\right)$ & Width $(1.4 \mathrm{~m})$ \\
\hline Influent flow rate $\left(0.2 \mathrm{~m}^{3} / \mathrm{day}\right)$ & Length $(2.8 \mathrm{~m})$ \\
\hline Mean Influent BOD $(1135.5 \mathrm{mg} / \mathrm{L})$ & Depth $(1.2 \mathrm{~m})$ \\
\hline Net Evaporation $(15 \%$ of pond Area) & Area $\left(3.91 \mathrm{~m}^{2}\right)$ \\
\hline Pond shape (Rectangular) & Volume $\left(4.7 \mathrm{~m}^{3}\right)$ \\
\hline
\end{tabular}

Table 2: Design parameters, details and configuration of the Constructed WSP.

\section{Kinetic model design}

The simple approach to the rational design of facultative pond assumes they are completely mixed reactors in which $\mathrm{BOD}_{5}$ removal follows first-order kinetics. The rational equation for the design is given as:

$$
\frac{L_{e}}{L_{i}}=\frac{1}{\left(1+k_{1} t\right)}
$$

where, $L_{i}$ is the influent wastewater BOD $(m g / L), L_{e}$ is effluent (treated) wastewater BOD (mg/L) and $\mathrm{t}$ is Retention time; (days).

Rearranging equation (2):

$$
t=\frac{L_{i}}{L_{e}}-1\left(\frac{1}{k_{1}}\right)
$$

The area of the pond is calculated using the below equation:

$$
A=\frac{Q_{t}}{D}
$$

where, $\mathrm{Q}$ is the wastewater volumetric flow rate $\left(\mathrm{m}^{3} /\right.$ day $)$ and $\mathrm{D}$ is the Pond depth (m), and A is the area of pond $\left(\mathrm{m}^{2}\right)$.

Substituting "t" from equation (2) into equation (3) the area becomes:

$$
A=\left(\frac{Q}{D K_{1}}\right)\left(\frac{L_{i}}{L_{e}-1}\right)
$$

The value of $\mathrm{k}_{1}$ at $20^{\circ} \mathrm{C}$ was found to be 0.3 day $^{-1}$; and its variation with temperature $\mathrm{T}$ is described by the Arrhenius equation below:

$$
k_{T}=k_{20} \theta^{T-20}
$$

where, $\Theta$ is the Arrhenius constant, whose value is usually between
1.01-1.09. The Urban water technology centre, Dundee proposed value of $\Theta$ as 1.05 and equation (5) becomes:

$$
k_{T}=0.3(10.5)^{28-20}
$$

Hence from equation (6) above, using the mean air temperature in the coldest season in Kaduna as given in the above data,

$$
\begin{aligned}
& k_{T}=0.3(10.5)^{28-20} \\
& k_{T}=0.4 d a y^{-1}
\end{aligned}
$$

Using equation (3), the retention time; $\mathrm{t}$ is calculated;

$t=\left[\left(\frac{1135.5}{113.55}\right)-1\right]\left(\frac{1}{0.44}\right)$

$\mathrm{t}=20.45$ days.

This is approximately 21 days.

$$
A=\left(\frac{Q}{D K_{1}}\right)\left(\frac{L_{i}}{L_{e}-1}\right)
$$

From equation 4, the pond area is calculated as:

$$
A=\left(\frac{0.2}{1.2 \times 0.44}\right)\left(\frac{1335.5}{113.55}-1\right)
$$

$\mathrm{A}=3.4 \mathrm{~m}^{2}$

Considering area increase of $15 \%$ for net evaporation:

$\mathrm{A}=1.15 \times 3.4$

$\mathrm{A}=3.91 \mathrm{~m}^{2}$

The Pond Volume for a rectangular shaped pond is given as;

$\mathrm{V}=\mathrm{A} \times \mathrm{D}$

$\mathrm{V}=3.91 \times 1.2=4.692 \mathrm{~m}^{3}$ Approximately $4.7 \mathrm{~m}^{3}$

The length- width ratio for stabilization pond is within the range of 2-3:1;

Taking a length-width ratio; $\mathrm{L} / \mathrm{W}$ of 2:1

$\frac{L}{W}=\frac{2}{1}=2$

Hence,

$L=2 W$

But:

$A=L \times W=2 W \times W=2 W^{2}$

Therefore,

$A=2 W^{2}=3.91$

$W=\sqrt{1.955}=1.398$

Hence:

$\mathrm{L}=2 \mathrm{~W}=2 \times 1.398=2.8 \mathrm{~m}$

Conversion of total pond volume from $\mathrm{m}^{3}$ to liters: 
Citation: Okonkwo PC, Musa U (2017) Evaluation of Design and Operational Parameters of Pilot Single Stage Stabilization Pond for Treatment of Brewery Waste Water Effluent. J Adv Chem Eng 7: 178. doi: 10.4172/2090-4568.1000178

Page 3 of 7

Conversion factor: 1000 liters $=1 \mathrm{~m}^{3}$

\section{$4.7 \times 1000=4700$ liters}

The construction and operational stages of the pond are shown in Figures 1-3.

\section{Materials and Methods}

The brewery wastewater effluents were collected from a brewing industry at Kudenda industrial layout, Kaduna. The discharge point into the receiving stream is situated at Latitude $10^{\circ} 28.043^{\prime} \mathrm{N}$, Longitude $7^{\circ} 23.194^{\prime}$ E and elevation $592.3 \mathrm{~m}$ above sea level.

The brewery wastewater samples were collected for a period of 27 days analyzed according to the methods of wastewater Quality

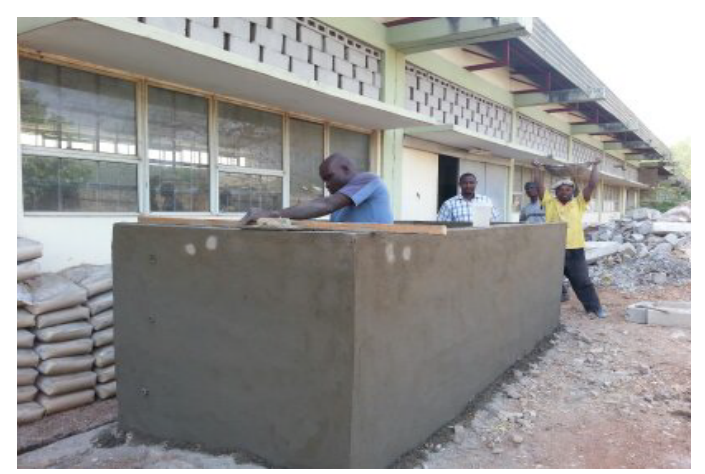

Figure 1: Pond under construction.

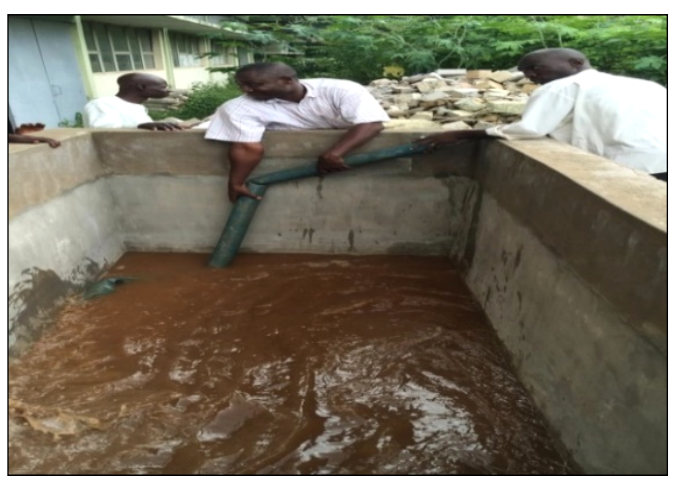

Figure 2: Wastewater discharged into the pond.

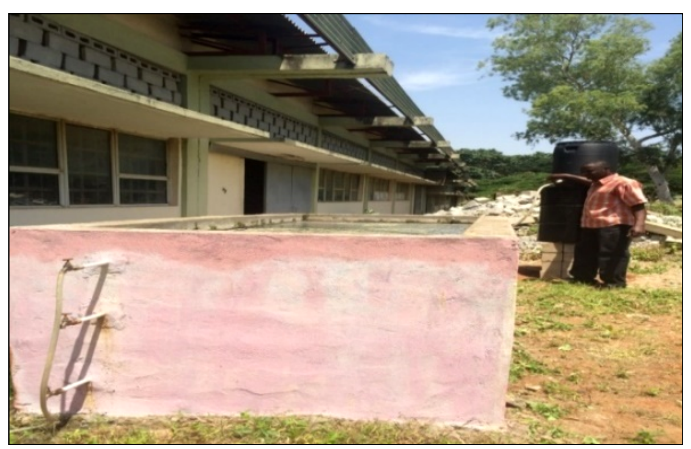

Figure 3: Pond operated to stabilize wastewater. assessment described in "Standard methods for the examination of water and wastewater of American Public Health Association [8]. The results of the analyses are presented in Table 3 and were considered for the design calculations.

\section{Results and Discussion}

The results of the analysis of the parameters of the raw and treated wastewater and the performance efficiencies of the WSP are presented in Tables 3-5.

High BOD and COD levels indicates decline in DO because the oxygen that is available in the wastewater is being consumed by the bacteria and this will lead to the inability of fish and other aquatic organisms to survive in the wastewater receiving stream and river. The analysis of the brewery wastewater effluent carried out showed that the range of the $\mathrm{BOD}_{5}$ and COD of the wastewater are (800-1805) $\mathrm{mg} / \mathrm{L}$ and (1504-3393.4) $\mathrm{mg} / \mathrm{L}$ with average values of $1128 \mathrm{mg} / \mathrm{L}$ and 2122.1 $\mathrm{mg} / \mathrm{L}$ respectively as presented in Table 4 .

These values are higher than the recommended limits for discharge by NESREA (See Table 4) and this makes the wastewater unsuitable for direct discharge into the receiving water bodies since it may have negative effects on the quality of the stream water and subsequently cause harm to the aquatic life, animals and man [9]. The time profile of $\mathrm{BOD}_{5}$ and $\mathrm{COD}$ for the treated wastewater as fitted on the polynomial curves are presented in Figures 4 and 5.

From these curves, the $\mathrm{R}^{2}$ values for the $\mathrm{BOD}_{5}$ and the COD curves are 0.9905 and 0.9728 respectively. The $R^{2}$ value is always between 0 and 1 . The model is stronger and predicts better response when $\mathrm{R}^{2}$ value is

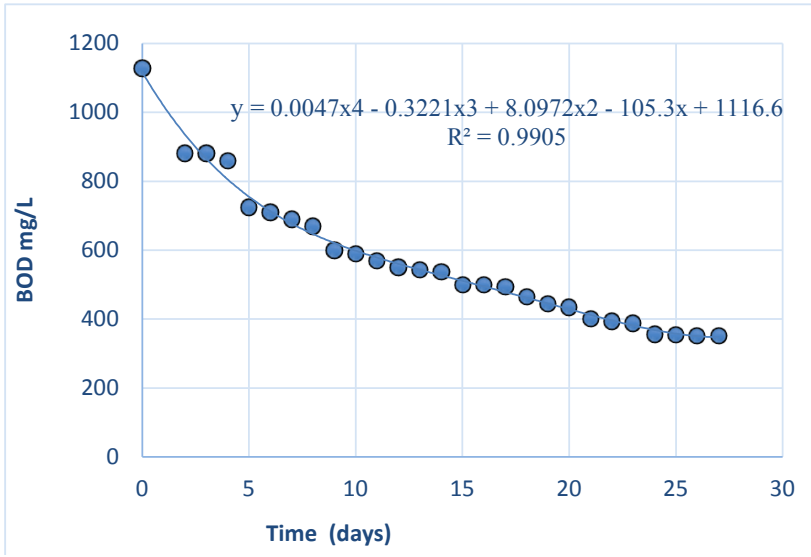

Figure 4: Time profile of BOD.

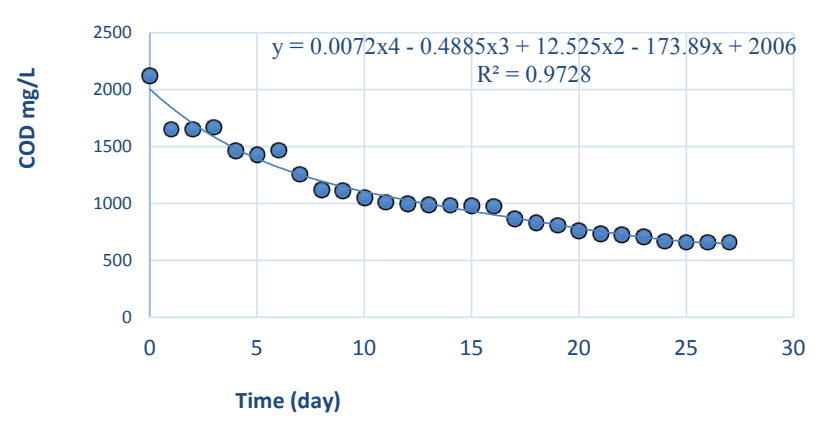

Figure 5: Time profile of COD. 
Citation: Okonkwo PC, Musa U (2017) Evaluation of Design and Operational Parameters of Pilot Single Stage Stabilization Pond for Treatment of Brewery Waste Water Effluent. J Adv Chem Eng 7: 178. doi: 10.4172/2090-4568.1000178

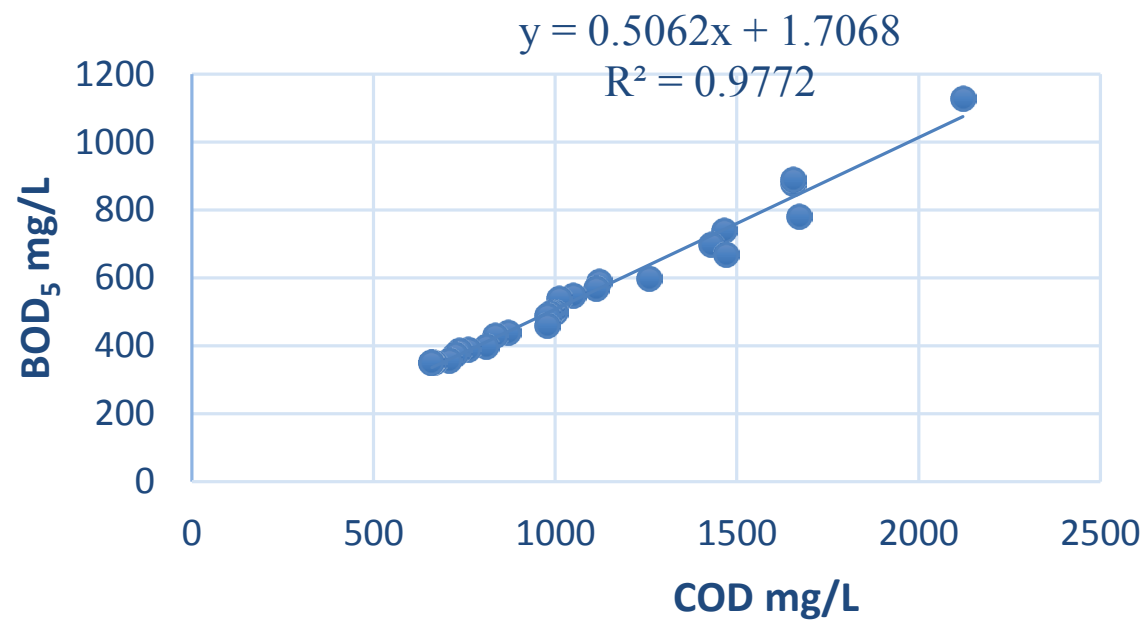

Figure 6: Correlation of $\mathrm{BOD}_{5}$ and $\mathrm{COD}$.

\begin{tabular}{|c|c|c|c|c|c|c|c|c|c|c|}
\hline \multirow{2}{*}{$\begin{array}{c}\text { Ret. } \\
\text { time (day) }\end{array}$} & \multicolumn{2}{|c|}{$\mathrm{BOD}_{5}(\mathrm{mg} / \mathrm{L})$} & \multicolumn{2}{|c|}{$\operatorname{COD}(\mathrm{mg} / \mathrm{L})$} & \multicolumn{2}{|c|}{ TSS (mg/L) } & \multicolumn{2}{|c|}{ Turbidity (mg/L) } & \multicolumn{2}{|c|}{$\mathrm{EC}(\mu \mathrm{S} / \mathrm{cm})$} \\
\hline & RS & TS & RS & TS & RS & TS & RS & TS & RS & TS \\
\hline 1 & 1650 & 880 & 3102 & 1654.4 & 1200 & 400 & 7.2 & 5.0 & 1470 & 1280 \\
\hline 2 & 1250 & 880 & 2350 & 1654.4 & 1200 & 400 & 6.5 & 4.5 & 1180 & 1280 \\
\hline 3 & 1805 & 890 & 3393.4 & 1673.2 & 1000 & 400 & 4.6 & 2.2 & 1630 & 970 \\
\hline 4 & 1110 & 780 & 2086.8 & 1466.4 & 1000 & 400 & 5.7 & 2.3 & 1120 & 910 \\
\hline 5 & 1300 & 740 & 2444 & 1430 & 1000 & 400 & 5.0 & 2.1 & 960 & 610 \\
\hline 6 & 990 & 700 & 1861.2 & 1470.4 & 1000 & 400 & 6.2 & 2.2 & 1020 & 610 \\
\hline 7 & 1200 & 670 & 2256 & 1258.4 & 1000 & 200 & 6.1 & 2.2 & 1000 & 700 \\
\hline 8 & 900 & 600 & 1692 & 1122 & 1000 & 200 & 6.0 & 2.1 & 1000 & 695 \\
\hline 9 & 1500 & 590 & 2828 & 1112.8 & 1000 & 200 & 6.2 & 2.2 & 940 & 640 \\
\hline 10 & 900 & 570 & 1692 & 1050.5 & 1000 & 200 & 6.1 & 2.4 & 980 & 620 \\
\hline 11 & 1000 & 550 & 1880 & 1010 & 1000 & 200 & 6.0 & 2.5 & 870 & 410 \\
\hline 12 & 890 & 540 & 1673.2 & 1001 & 1200 & 200 & 6.0 & 2.2 & 902 & 400 \\
\hline 13 & 800 & 535 & 1504 & 990 & 1000 & 200 & 6.2 & 2.1 & 890 & 400 \\
\hline 14 & 1110 & 500 & 2086.8 & 985 & 1000 & 200 & 6.5 & 2.1 & 900 & 370 \\
\hline 15 & 900 & 495 & 1692 & 980 & 1000 & 200 & 6.3 & 2.1 & 800 & 360 \\
\hline 16 & 905 & 490 & 1701.4 & 978 & 1000 & 200 & 6.4 & 2.0 & 770 & 355 \\
\hline 17 & 910 & 460 & 1710.8 & 870 & 1100 & 190 & 6.5 & 2.0 & 710 & 350 \\
\hline 18 & 900 & 440 & 1692 & 835 & 1100 & 195 & 6.5 & 1.8 & 715 & 330 \\
\hline 19 & 905 & 430 & 1701.4 & 810 & 1120 & 195 & 6.6 & 1.9 & 716 & 325 \\
\hline 20 & 906 & 400 & 1703.3 & 760 & 1200 & 190 & 6.6 & 2.0 & 700 & 305 \\
\hline 21 & 1000 & 390 & 3102 & 736 & 1200 & 198 & 7.2 & 2.1 & 1470 & 300 \\
\hline 22 & 1250 & 385 & 2350 & 725.5 & 1000 & 198 & 6.5 & 2.0 & 1180 & 295 \\
\hline 23 & 1005 & 375 & 3393.4 & 708 & 1000 & 199 & 4.6 & 2.0 & 1330 & 290 \\
\hline 24 & 1110 & 355 & 2086.8 & 669 & 1000 & 200 & 5.7 & 2.0 & 1120 & 287 \\
\hline 25 & 1300 & 350 & 2444 & 660 & 1000 & 199 & 5.0 & 2.0 & 960 & 287 \\
\hline 26 & 990 & 350 & 1861.2 & 660 & 1000 & 199 & 6.2 & 2.0 & 1050 & 287 \\
\hline 27 & 1200 & 350 & 2256 & 660 & 1000 & 199 & 6.1 & 2.0 & 1000 & 287 \\
\hline
\end{tabular}

RS- Raw wastewater Sample, TS- Treated water Sample

Table 3: Results of the analysis of the raw and treated brewery wastewater. 
Citation: Okonkwo PC, Musa U (2017) Evaluation of Design and Operational Parameters of Pilot Single Stage Stabilization Pond for Treatment of Brewery Waste Water Effluent. J Adv Chem Eng 7: 178. doi: 10.4172/2090-4568.1000178

Page 5 of 7

\begin{tabular}{|c|c|c|c|c|}
\hline Parameter & Range & Mean & Treated sample & NESREA limit \\
\hline BOD $_{5}(\mathrm{mg} / \mathrm{L})$ & $800-1805$ & 1128.8 & 350 & 30 \\
\hline COD $(\mathrm{mg} / \mathrm{L})$ & $1504-3393.4$ & 2122.1 & 199 & 30 \\
\hline TSS $(\mathrm{mg} / \mathrm{L})$ & $1000-1200$ & 1048.9 & 2.0 & 30 \\
\hline Turbidity $(\mathrm{NTU})$ & $4.6-7.2$ & 6.09 & 25 & Not Specified (900 By WHO) \\
\hline EC $(\mu \mathrm{S} / \mathrm{cm})$ & $700-1630$ & 1011.8 & 287 & \\
\hline
\end{tabular}

Table 4: Analysis of Raw and Treated wastewater compared with NESREA Limits.

\begin{tabular}{|c|c|c|c|}
\hline S/NO & Parameters & Unit & Efficiency (\%)/ Rate constant \\
\hline 1 & BOD $_{\mathbf{5}}$ & $\mathrm{mg} / \mathrm{L}$ & 69 \\
\hline 2 & COD & $\mathrm{mg} / \mathrm{L}$ & 68.9 \\
\hline 3 & TSS & $\mathrm{mg} / \mathrm{L}$ & $\mathrm{NTU}$ \\
\hline 4 & Turbidity & $\mu 1$ \\
\hline 5 & EC & DS/cm & 71.2 \\
\hline 6 & BOD Removal Rate constant & 71.6 \\
\hline
\end{tabular}

Table 5: Efficiency and BOD removal rate constant of the Constructed WSP.

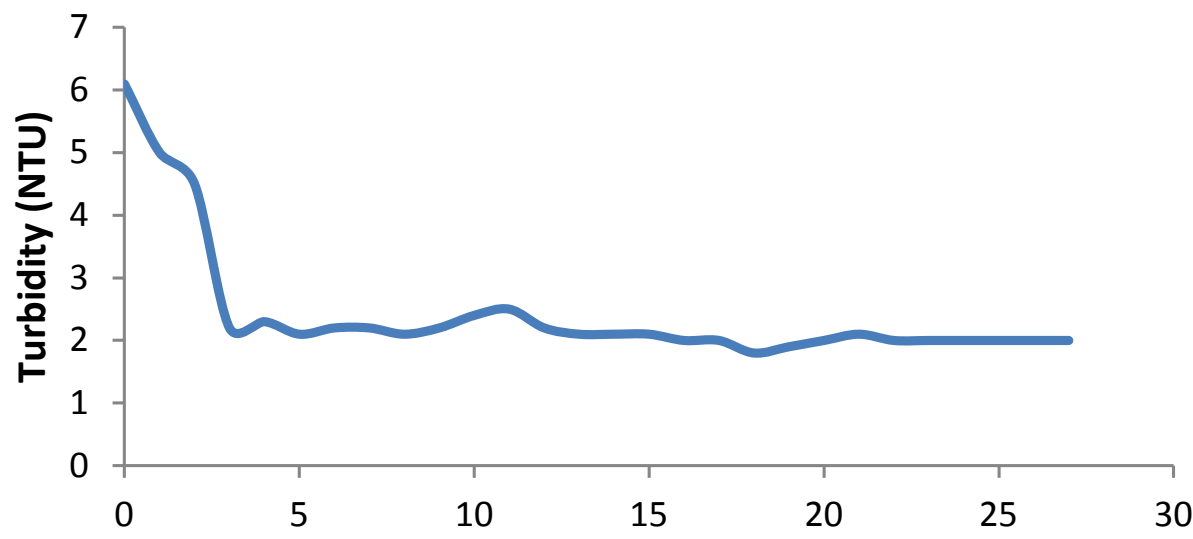

Time (day)

Figure 7: Time profile of Turbidity.

closer to 1, [3]. The plot of $\mathrm{BOD}_{5}$ versus $\mathrm{COD}$ indicated $\mathrm{R}^{2}$ of 0.9772 as presented in Figure 6 and predicted the correlation between $\mathrm{BOD}_{5} \mathrm{COD}$ as: $\mathrm{BOD}_{5}=0.5062(\mathrm{COD})+1.7068$. This will be useful for the estimation of COD from BOD data and also ease the calculations of $\mathrm{BOD}_{5} / \mathrm{COD}$ ratios in order to predict the biodegradability of the wastewater.

The $\mathrm{BOD}_{5}$ and $\mathrm{COD}$ value obtained for the treated wastewater in the pond at the retention period of 25 days are $350 \mathrm{mg} / \mathrm{L}$ and 660 $\mathrm{mg} / \mathrm{L}$ respectively. Although these values did not meet the NESREA limits for discharge into receiving water bodies, there was a significant reduction in the wastewater pollution loading and further reduction can be achieved with further stabilization in secondary facultative or the maturation ponds.

The turbidity and the total suspended solids of wastewater are indications of the water clarity [10]. The turbidity of the wastewater ranged from 4.6 to $7.2 \mathrm{NTU}$ for the period of the study; and the mean value was 6.09 NTU. Similarly, the range of the TSS measured for the raw wastewater is 1000 to $1200 \mathrm{mg} / \mathrm{L}$ and the mean value is $1040 \mathrm{mg} / \mathrm{L}$. The TSS mean value was higher than the NESREA limits [11] for brewery wastewater discharge as presented in Table 4 . Excessive turbidity and
TSS in water causes problem with water purification processes such as flocculation and filtration, which may increase treatment cost. High turbid waters also affect the sights of most aquatic lives. The Turbidity-time curve for the WSP treated wastewaters is presented in Figure 7. There was a sharp reduction in turbidity in the first 3 days of the retention period and later became gradually steady with little fluctuations over the remaining retention time. The turbidity was reduced from an average value of 5.96 to $2.0 \mathrm{NTU}$ which implied $67.2 \%$ reduction (see Table 4). The time profile of TSS presented in Figure 8 have similar pattern which the turbidity curve. The sharp decline in the curves in the earlier days was as a result of high level of suspended solids in the wastewater and hence causing the quick sedimentation of heavier particles due to gravitational pull. Further decline in TSS are as a result of further gradual sedimentation of particles, the activities of algae and bacteria in the decomposition of suspended organic matters.

The range of the electrical conductivities of the brewery wastewater is from 940 to $1630 \mu \mathrm{s} / \mathrm{cm}$ and the mean value was $1130 \mu \mathrm{s} / \mathrm{cm}$ as shown in Table 4. Although there is no specified NESREA [11] limit for EC, this mean value exceeded the World Health Organization (WHO) 


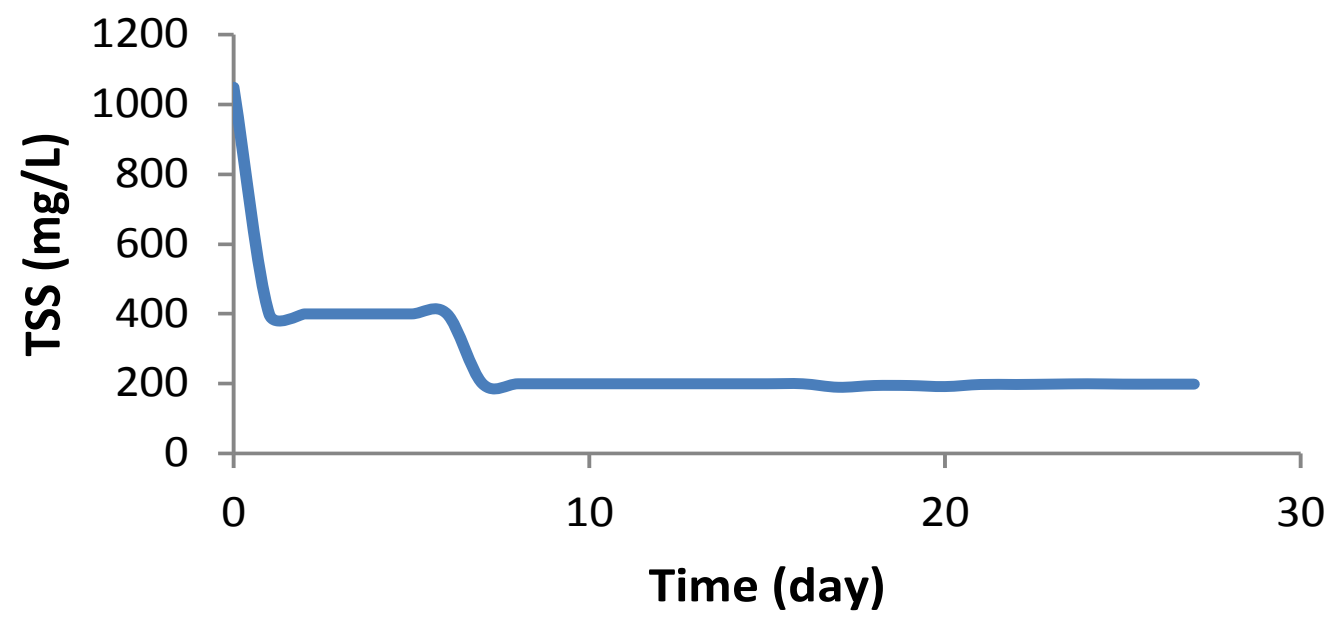

Figure 8: Time profile of TSS.

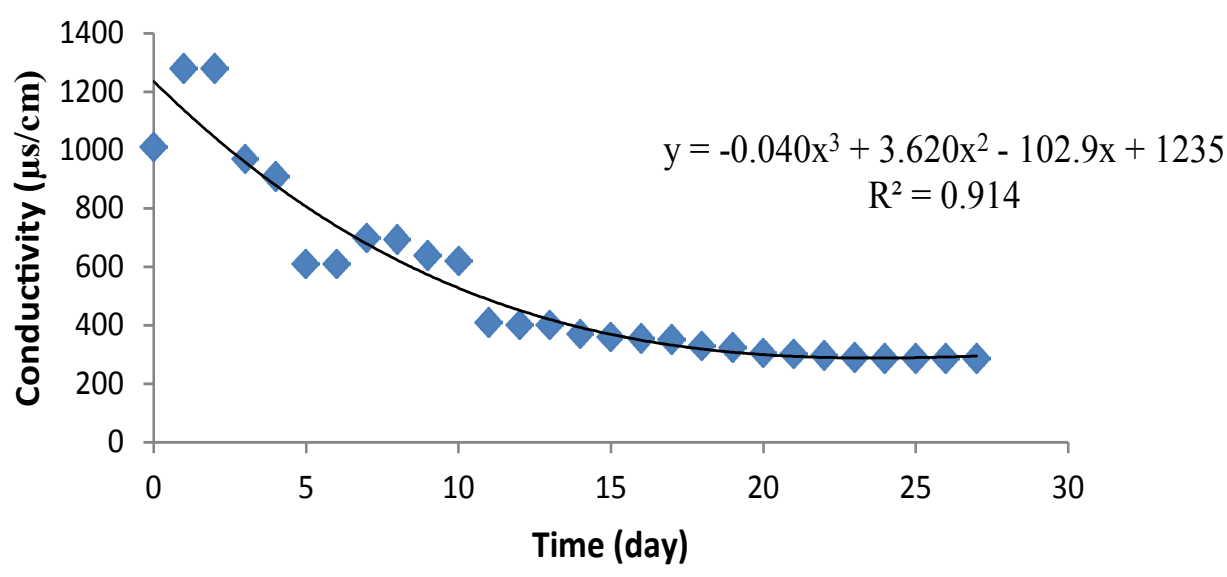

Figure 9: Time profile of conductivity.

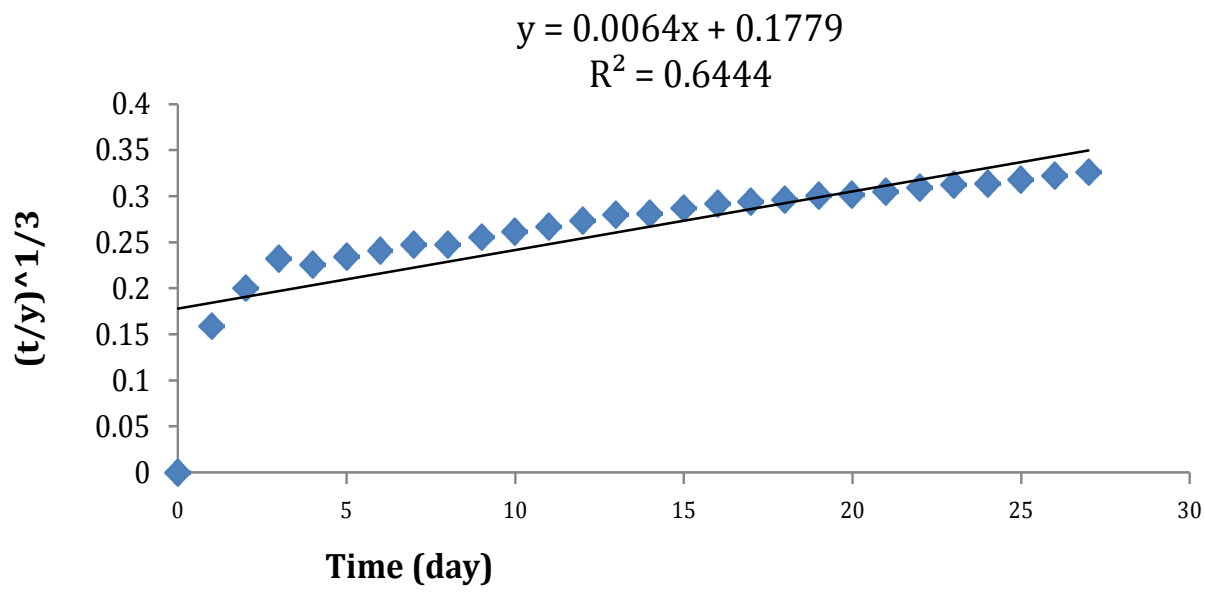

Figure 10: $(t / y)^{1 / 3}$ vs time. 
Citation: Okonkwo PC, Musa U (2017) Evaluation of Design and Operational Parameters of Pilot Single Stage Stabilization Pond for Treatment of Brewery Waste Water Effluent. J Adv Chem Eng 7: 178. doi: 10.4172/2090-4568.1000178

limit of $900 \mu \mathrm{s} / \mathrm{cm}$ for industrial waste water discharge. Electrical conductivity is a useful indicator of mineralization and salinity or total salt in a water sample. High EC can also increase the corrosive nature of the wastewater. High EC of the wastewater can increase rate of soil erosion. High EC can also increase corrosion rate in metallic tanks/ containers and wastewater pipelines. The EC-time profile is presented in in Figure 9. The EC was reduced from mean value of 1130 to 287 $\mu \mathrm{s} / \mathrm{cm}$ which is $71.6 \% \mathrm{EC}$ removal, as presented in Table 5 . This value conformed to wastewater discharge limits by WHO [12].

The reaction rate constant for $\mathrm{BOD}_{5}$ removal was evaluated using Thomas' method. This is obtained by the plot of $(t / y)^{1 / 3}$ versus time and $t$ is the retention in days, while $y$ is the $\mathrm{BOD}_{5}$ in $\mathrm{mg} / \mathrm{L}$ as shown in Figure 10. The $\mathrm{BOD}_{5}$ removal rate constant $\mathrm{k}$; calculated was 0.088 per day. The reaction rate constant is an important parameter used in the design calculations of WSP. Ref. [13] obtained a $\mathrm{BOD}_{5}$ removal rate constant of 0.27 per day for WSP sewage treatment in in south eastern Nigeria. The value of the reaction rate constant depends on climatic conditions and type/nature of wastewater.

The performance of the constructed WSP was evaluated in terms $\mathrm{BOD}_{5}$, COD, TSS, Turbidity and EC removal/reductions. The WSP efficiency based on these measured parameters were $69 \% 68.9 \%, 81 \%$, $67.2 \%$ and $71.6 \%$ respectively as presented in Table 4 . The BOD-COD correlation was $\mathrm{BOD}=0.531 \mathrm{COD}-1.960$. The $\mathrm{BOD}$ removal regression model was: $\mathrm{BOD}=0.0001 \mathrm{t}^{5}-0.0034 \mathrm{t}^{4}-0.1419 \mathrm{t}^{3}+6.6096 \mathrm{t}^{2}-102.09 \mathrm{t} 1114.5$.

\section{Conclusions}

It can be concluded from this studies that WSP can be employed as an alternative method for the treatment of brewery wastewater treatment. The performance efficiency of the pilot scale WSP for the removal/reduction of $\mathrm{BOD}_{5}, \mathrm{COD}$, TSS, Turbidity and EC for the wastewater was $69 \% 68.9 \%, 81 \%, 67.2 \%$ and $71.6 \%$ respectively. The design, operational and kinetic parameters obtained can be employed in the design and construction of industrial scale WSP for brewery wastewater effluents.

\section{References}

1. Adekunle AS, Eniola ITK (2008) Impact of Industrial Effluents on Quality of Segment of Asa River within an Industrial Estate in Ilorin, Nigeria. New York Science Journal 01: 17-21.

2. Agunwamba JC (1994) Field pond performance and design evaluation using physical models. Water Resources 26: 1403-1407.

3. Olukanni DO, Ducoste JJ (2011) Optimization of Waste Stabilization Pond Design for Developing Nations using Computational Fluid Dynamics. Ecological Eng 37: 1878-1888.

4. Arthur JP (1983) Notes on the design and operation of waste stabilization ponds in warm climates developing countries. World Bank, Washington DC, USA.

5. Mara DD (2001) Appropriate wastewater collection, treatment and reuse in developing Countries Proceedings of the Institutions of Civil Engineers, London, UK, pp: 299-303.

6. Mara DD, Pearson HW (1998) Design manual for waste stabilization pond Mediterranean countries, European Investment Bank, Lagoon Technology International. Leeds, United Kingdom.

7. Mohammed B (2006) Design and performance evaluation of wastewater treatment Unit, AU JT 9: 193-198.

8. American Public Health Association (APHA) (2010) Standard Methods for the Examination of Water and Wastewater. 20th edn. APHA, Washington DC, USA.

9. Agunwamba JC (2001) Effect of tapering on the performance of waste stabilization ponds. Water Resources 35: 1191-1200.

10. Environmental Protection Agency (EPA) (2000) Parameters of Water Quality, Interpretation and Standards. EPA, Ireland.

11. National Environmental Standards and Regulations Enforcement Agency (NESREA) (2005) Guidelines to Standards for Environmental Pollution Control in Nigeria, Federal Government Press Lagos, Nigeria.

12. WHO (2000) Global Water Supply and Sanitation Assessment 2000 Report.

13. Agunwamba JC (2001) Waste Engineering and management tools, Immaculate Publications Ltd.No. 2 Aku Street, Ogui N/layout, Enugu, Nigeria. 